\title{
I GIVE AT THE OFFICE: A REVIEW OF WORKPLACE GIVING RESEARCH, THEORY, AND PRACTICE
}

\author{
Genevieve G. Shaker* \\ Associate Professor of Philanthropic Studies \\ Indiana University, Lilly Family School of Philanthropy \\ Indiana University Purdue University Indianapolis \\ 301 University Blvd., University Hall 3000 \\ Indianapolis, IN 46202 USA \\ gshaker@iupui.edu 317-278-1058 \\ Robert K. Christensen \\ Associate Professor \\ Romney Institute of Public Management \\ Brigham Young University
}

\begin{abstract}
Workplace giving is a widely used philanthropic tool. While it has great unmet potential it is also facing a number of challenges, including competition from informal crowdfunding campaigns. In the face of such challenges, we take stock of the extant research to better understand the value and future of workplace giving, including more firmly understanding employee actions and preferences. Workplace giving studies can augment knowledge about contextual giving or bounded settings for exploring basic philanthropic questions (e.g., donor control or gift elasticity). We use a three-part conceptual framework to synthesize and discuss research on individual workplace giving in the context of broader giving behaviors. We address what researchers know, do not know, and need to know on the topic of workplace giving.
\end{abstract}

Keywords: workplace giving, employee giving, payroll giving, workplace campaigns

This is the author's manuscript of the article published in final edited form as:

Shaker, G. G., \& Christensen, R. K. (2018). I give at the office: A review of workplace giving research, theory, and practice. International Journal of Nonprofit and Voluntary Sector Marketing. https://doi.org/10.1002/nvsm.1628 


\section{Introduction}

Workplace giving occurs when employees make financial donations for charitable purposes with implicit employer endorsement (Barman, 2006; Shaker, 2013a). Workplace campaigns constitute the strategies that employers use to encourage employees' philanthropy. Campaigns take place in countries around the world (Haski-Leventhal, 2013; Romney-Alexander, 2002; Wiepking \& Handy, 2015), but appear to be most common in the United States where its roots date to the late 1800s (Barman, 2006; Scaife, McGregor-Lowndes, Barraket, \& Burns, 2016).

In the U.S., employees gave \$4.2 billion through workplace campaigns in 2006-2007 (Giving USA, 2007) and current, if not empirically documented, estimates hover in the \$3-4 billion range (Shaker \& Christensen, 2017). In Australia, employees gave A \$43 million in 2014-2015, part of a multi-year upward trend (Australian Taxation Office, 2018). In 2016, U.K. employee donors gave $£ 291$ million by payroll deduction ( $3 \%$ of the $£ 9.7$ billion given overall in the U.K.), up by $2 \%$ from 2010 (Charities Aid Foundation (CAF), 2017). Workplace giving, therefore, is a transnational phenomenon (Breeze \& Scaife, 2015; Weipking \& Handy, 2015). It is also a phenomenon lacking suitable documentation and widespread understanding (Haski-Levanthal, 2012; Shaker, Christensen, \& Bergdoll, 2017). In this paper, we address one key dimension of workplace giving by exploring the research about who gives in workplaces.

Workplace campaigns serve various purposes: supporting community needs, building employee morale, loyalty, and satisfaction, influencing employees' tendency to be philanthropic, enhancing company image, serving the organization's corporate goals, and demonstrating good corporate citizenship (Barman, 2006; CECP, 2017; Potter \& Scales, 2008; Smith, 2013; Todd, 2015). In the U.S, workplace campaigns have been called the largest single mechanism through which nonprofits receive funds (Barman, 2006) and a key avenue by which working people (not the wealthy) make philanthropic contributions (National Committee for Responsive Philanthropy, 2003). In the U.K., workplace donations are thought to provide organizations with regular income and to provide access to new donors (Potter \& Scales, 2008; Romney-Alexander, 2002). In Australia, a national campaign is seeking to achieve a goal of one million annual workplace donors (Smyllie \& Arias, 2015).

Workplace giving emerged more than 100 years ago in the U.K., not long after it began in the U.S. (Barman, 2006; Potter \& Scales, 2008). The U.K. government made it tax-effective in 1987 and promotes it heavily but has gained limited momentum (CAF, 2017; Potter \& Scales, 2008; Romney-Alexander, 2002). Only $2 \%$ of U.K workplaces offer workplace giving (CAF, 2015). In Australia, less than $5 \%$ of employees in companies with workplace campaigns participate (Wilson, 2015). In the U.S., on the other hand, a 2003 study found that $25 \%$ of employees worked in companies with workplace campaigns and $35 \%$ of those employees participated (National Committee for Responsive Philanthropy, 2003). One, more recent survey of 100 
private workplaces concluded that as many as $80 \%$ of them offered payroll giving and that between 20-45\% of employees donated (America's Charities, 2013).

Workplace giving may have great unmet potential (CAF, 2015; CECP, 2015; Potter \& Scales, 2008; Scaife et al., 2016), but it is also facing a number of challenges to its viability. These include an increasingly crowded nonprofit/non-governmental sector, the ease of regular/monthly giving through bank accounts and credit cards, competition from peer-led informal workplace crowdfunding campaigns, the turn to contract employees and part-time personnel, more "active" approaches to engaging employees in corporate social responsibility programs, and changing giving preferences of the Millennial generation (Australian Charities Fund, 2016; Paarlberg \& Hwang, 2017; Shaker et al., 2017; Walker, 2016). A slowdown in the growth of payroll giving is observed in the U.K. and two large U.S. campaigns are in a long-term decline (CAF, 2017; CECP, 2015; Shaker \& Christensen, 2017).

In the face of both opportunity and challenge, researchers can help nonprofits and nongovernmental organizations better understand employee actions and preferences. Employers, many of whom are redoubling attention to corporate social responsibility programs, care about hosting successful fundraising campaigns (Lichtenstein, Drumwright \& Braig, 2004). Workplace giving studies can augment research about contextual giving or bounded settings for exploring basic philanthropic questions (e.g., donor control or gift elasticity). In the workplace setting, theories can be tested and results compared.

To create a resource for affected and interested parties, we use a three-part conceptual framework to synthesize and discuss research on individual workplace giving in the context of broader giving behaviors. In brief, we address what researchers know, do not know, and need to know on the topic.

\section{Method}

We conducted a literature search using multiple sources: academic databases (PsychoInfo, Sociological abstracts, EconLit, JStor, a One database search for smaller databases as well as publisher databases Emerald Insight, SpringerLink for the social sciences, Sage Journals Online, ScienceDirect), Google Scholar, citation lists of workplace giving articles, the IUPUI Payton Library Philanthropic Studies Index, Arnova abstracts, our own literature files. For our searches we used the key words/phrases: workplace giving, workplace donations, workplace campaigns, payroll giving, and matching campaigns/schemes. The search concluded in December 2017. We searched for scholarly studies and reports that were in English and addressed countries with advanced and established fundraising regimes (Breeze \& Scaife, 2015): Australia, Canada, France, Germany, Netherlands, Switzerland, U.K., and U.S. We found empirical research from the U.S., U.K., and Australia. U.S. literature was prevalent. We include discussion of select nonacademic reports that further illuminate or contextualize the scholarly literature. 


\section{Who gives in the workplace?}

The conceptual framework for this review aligns with Barman's (2007) assertation that workplace giving is influenced by micro-level, meso/dyadic-level, and macro-level dynamics. Individual employee demographics, characteristics, and traits are micro-level dynamics. Aspects of the relationship between the employer and the employee, characteristics of the employer, and the form of workplace giving are meso/dyadic-level dynamics. We categorize employee attitudes about giving at work the meso-level because but acknowledge the tie to the micro-level. The macro-level dynamics include the organizational field and broader environment in which the employers, employees, and beneficiaries must function.

Workplace giving researchers frequently use aspects of the micro-, meso-, macro- approach (Barman, 2007; Nesbit, Christensen \& Gossett, 2012; Shaker, Borden, \& Kienker, 2016; Shaker et al., 2017) but this analysis is the first to use the conceptual model for synthesizing research. Figure 1 offers a visualization of the framework and Figure 2 provides an overview of the variables discovered in our review. We recognize, in the nested depiction, the overlap between some of the dimensions. For example, workplace factors (meso) may mediate individual level (micro) factors' relation to the broader context (macro) in which the workplace campaigns function.

Figure 1: Conceptual Framework of Dynamics for Understanding Individuals' Workplace Giving Behaviors

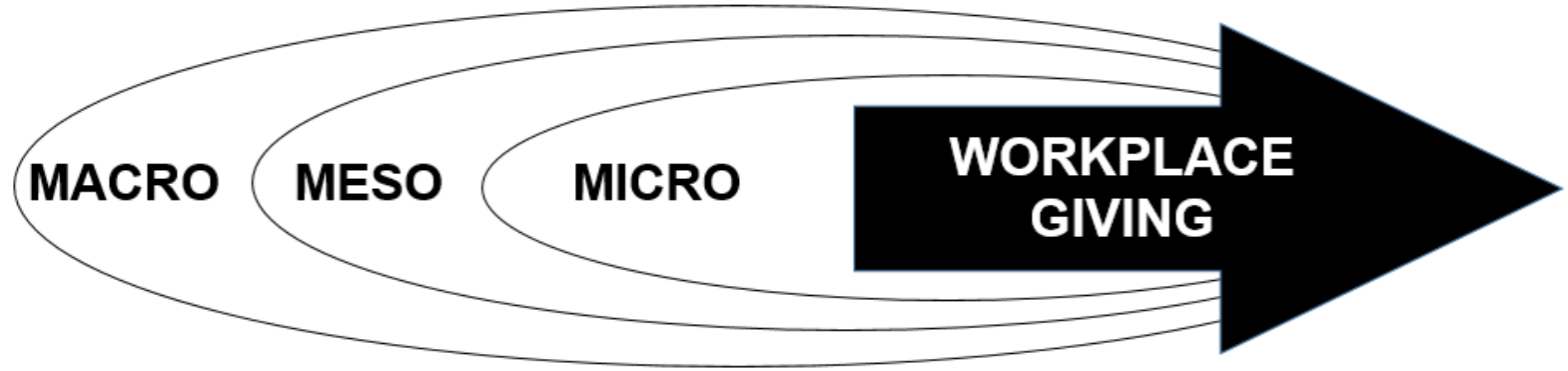

Figure 1. Visualization of the dynamics relevant to workplace giving decisions. The depiction is adapted from prior scholarly work (Barman, 2007; Nesbit, Christensen \& Gossett, 2012; Shaker, Borden, Kienker, 2016; Shaker et al., 2017) and expanded to indicate the nested and overlapping nature of macro-, meso-, and micro-level dynamics. 
Figure 2: Individual Workplace Giving Variables Aligned with the Conceptual Framework

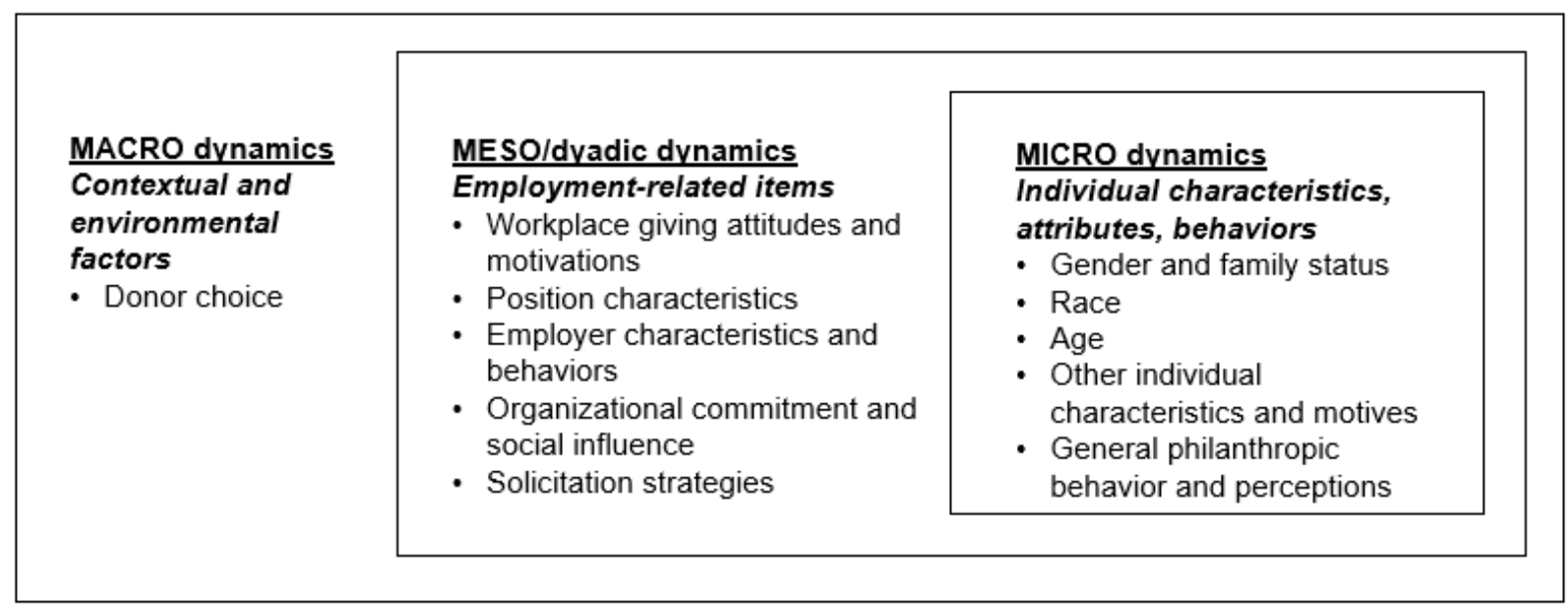

Figure 2. Visualization of the variables relevant to workplace giving decisions, aligned with the conceptual framework and paper organization. The depiction indicates the nested and overlapping nature of macro-, meso-, and micro-level dynamics.

\section{Micro/within dynamics}

Researchers have closely examined how individual attributes - including gender, race, age, education, philanthropic giving, volunteering, religiosity, marital status - influence philanthropic behavior (Andreoni, Brown, \& Rischall, 2003; Brown, 2005; Gittell \& Tibaldi, 2006; Musick \& Wilson, 2008; Wu, 2004). Not surprisingly, researchers have also studied the influence of individuals' personal characteristics, attributes, perceptions, and behaviors in workplace giving.

\section{Gender and family status.}

While not definitive, women have been found to be more likely to donate than men, but not necessarily to donate more money than men (Wiepking \& Bekkers, 2012). Workplace studies lack consensus regarding gender but show some general agreement with broader trends. An early U.S. study of employees from five San Francisco workplaces $(n=548)$ found that women were slightly (though not significantly) more likely to give than men (Witty \& Urla, 1989). Gender was not significant in predicting donations or donation amounts in a U.S. study with a nationally representative sample (Osili, Hirt, \& Raghavan, 2011) and three that were set within universities (Charoensap-Kelly, 2017; Knight, 2004; Nesbit et al., 2012). In three other single organization studies - a regional bank, a large U.S. company, and a university-women were most likely to participate in campaigns (Agypt, Christensen, \& Nesbit, 2012; Borden, Shaker, \& Kienker, 2014; Carman, 2004; Christensen, Nesbit, \& Agypt, 2016; Leslie, Snyder, \& Glomb, 2013), but findings about whether they gave more or less were mixed (Agypt et al., 2012; Carman, 2004; Leslie et al., 2013), and the findings were not always significant. 
In the U.K., a workplace giving study based on 3-year pooled data from the Office of National Statistics found that more men donated through the workplace than women (Potter \& Scales, 2008). The study also found that $50 \%$ of men only gave through payroll donations as compared to $30 \%$ of women. Another U.K. study noted that payroll giving campaigns traditionally targeted the mostly-male manufacturing industries, perhaps giving an indication of why men were more socialized to participate (Romney-Alexander, 2002). In an Australian survey of 4500 employees at 24 companies, $35.5 \%$ of women gave as compared to $29.3 \%$ of men and men were significantly more likely to be "high-level" donors than women (Haski-Levanthal, 2012).

It is notable that philanthropic giving is often a family affair and that individuals who are single may behave differently than those who are married (Wiepking \& Bekkers, 2012). Marriage is usually, though certainly not exclusively, found to be positively related to giving incidence (Mesch, 2006; Mesch, Rooney, Steinberg, \& Denton, 2006; Wiepking \& Bekkers, 2012). The "before paycheck" nature of most payroll donations may affect these dynamics, however. To this point, Osili et al. (2011) reported that marital status and number of children were insignificant in employees' workplace gifts but significant for external giving. In Australia, partnered employees with children living at home were more likely to be high-level donors than partnered employees without children at home (Haski-Levanthal, 2012). Of all the family groups, single parents with children at home were most likely to be nondonors or low-level donors and least likely to be high-level donors.

\section{Race.}

In the United States, more Caucasians donate than individuals from other racial and ethnic groups (Bekkers \& Wiepking, 2011a). Only a few, U.S.-based workplace studies examined race and the finding was similar. Witty and Urla (1989) found that White, Black, and Hispanic employees participated in their workplace campaigns at similar rates (76\%-79\%). Osili et al. (2011) found that race was less significant inside the workplace than out for the full study sample $(n=6,009)$; when considering only those respondents with workplace campaigns race became insignificant in the workplace. Two university-based studies found being White significantly predicted giving (Borden et al., 2014; Knight, 2004). Individuals who are different from the majority population in their workplace are usually less organizationally attached (O'Reilly, Caldwell, \& Barnett, 1989), suggesting that the effects of race on workplace giving may be better studied at the meso-level as a result of social/peer influence.

Age.

Increased age is typically a marker for increased giving, with some exceptions when controlling for other factors (Bekkers \& Wiepking, 2011a; Brown \& Ferris, 2007; Rooney, Steinberg, \& Schervish, 2001). This mostly holds true in the workplace - but appears to be mediated by the natural progression of one's career. In the U.K., Potter and Scales' (2008) study of national data showed that workers in their 30s and 40s were the most likely workplace donors. In Australia, 
those in a "high-level" giving group gave more as they aged - until the age of 55 at which point their giving declined (Haski-Leventhal, 2012). Among "low-level" givers, the giving rate through age 55 was consistent and then rose (with significance) after age 56. In Carman's (2004) study of a large U.S. bank with 75,000 employees, giving likelihood rose with age and had a positive (but insignificant) effect on contribution amount. Osili et al. (2011) similarly found that age was significant and positively related to giving at work in their multi-workplace study, though with declining importance as the donor aged.

Whether employers are prepared to meet aging employees changing priorities and desires can effect employees' levels of organizational commitment (Kooij, Jansen, Dikkers, \& De Lange, 2010), which in turn might influence their responsiveness to workplace-sponsored campaigns. This suggests the importance of also considering employees' workplace age - i.e. length of service - a meso/dyadic-level factor.

\section{Other individual characteristics and motives.}

Many workplace studies use organizationally-provided data with limited personal information. A few have probed further, but much remains unexamined. Educational level is a "ubiquitous correlate of charitable giving" (Bekkers \& Wiepking, 2011a, p. 344) but surprisingly few workplace studies include education as a variable. Haski-Leventhal's (2012) Australian study demonstrated that education significantly differentiated high-level givers from low-level givers. College attendance was insignificant for giving likelihood or amount in Osili et al.'s (2011) study. Conversly, Osili et al. (2011) found attendance at religious services-from the occasional to the frequent - to be significant in predicting both giving and giving amount. Nesbit et al. (2012) surveyed public university employees about their giving back to the university. Givers and nongivers attended religious services at the same rate, and religiosity was not a significant differentiator. More givers considered themselves liberals while more nongivers indicated that they were conservative.

Christensen, Nesbit, and Stritch (2017) found that individual motives matter to workplace giving. In their work, public service motivation (PSM) — an "individual's predisposition to respond to motives grounded primarily or uniquely in public institutions and organizations" (Perry \& Wise, 1990, p. 368) —was a positive predictor of workplace donations. Other researchers have found this public-oriented motivation to be a positive predictor for the donation of blood (Houston, 2006) and time (Christensen, Stritch, Kellough, \& Brewer, 2015).

\section{General philanthropic behavior and perceptions.}

Research has shown a connection among charitable behaviors (Meslin, Ronney, \& Wolf, 2008) and an increased likelihood among donors to donate again (Barber \& Levis, 2013). In the workplace there appears to be a similar interface. Knight (2004) discovered that participation in a prior campaign was a key determinant of giving again. Charoensap-Kelly (2017) noted that previous faculty/staff donors were 52 times more likely to donate again. Witty and Urla's (1989) 
study documented a significant positive difference in the size of workplace donations among those who were volunteers and civically active in comparison to their less-participatory coworkers. Haski-Levanthal's (2012) Australian high-level donors volunteered more at work and outside of work than low-level donors and gave more money outside the workplace than their coworkers. Workplace donations did not "crowd out" donations outside of the workplace (or vice versa) in two American studies (Nesbit et al., 2012; Osili et al., 2011). In the U.K., Potter \& Scales (2008) found that $40 \%$ of the payroll donors did not give in any other way. This suggests that workplace giving compliments giving outside of work, enhancing philanthropy, rather than threatening it.

Individuals hold views about the operations of nonprofit organizations that effect their giving behaviors (Bekkers \& Wiekpking, 2011b). These views can be influenced by personal experience, negative publicity regarding particular charities, and expectations regarding nonprofit/ngo activities, among other things. A few studies examine how these perceptions influence workplace campaign behavior. Giving was less likely among employees who thought the United Way was not a desirable workplace campaign organization than those who indicated otherwise (26\% versus 40\%) (Nesbit et al., 2013). Osili et al. (2011) discovered that workplace campaign participants evidenced high levels of confidence in nonprofits with greater significance for workplace giving than non-workplace giving. When giving is "filtered" through the workplace, trust or confidence in nonprofits appears particulary important for giving.

\section{Meso/dyadic dynamics}

In addition to individual-level dynamics, researchers have focused on the social relations between donors, their employing organizations, and benefiting nonprofit organizations (Healy, 2004; Straub, 2003). These relationships are part of a fuller understanding of workplace giving. In the workplace the employer is a campaign partner and promoter and a conduit through which employees support nonprofit missions. Characteristics of the employing organization and the employee-employer relationship (e.g. compensation, position, length of service), therefore, are relevant to understanding meso/dyadic dynamics. These factors appear to be consequential in workplace giving and introduce an additional "relational" aspect of charitable choice specific to this context, one found to be lacking in exclusively micro-level examinations (Ostrander \& Schervish, 1990). Some workplace examinations place factors such as salary and position level as micro-level individual demographics but others have termed these as relational "dyadic" attributes between the employee and the employer (Agypt et al., 2012; Shaker et al., 2016). We believe that these individual attributes are formed in concert with the employer (and are often organizationally controlled), take the latter perspective, and include them among the meso/dyadic level factors. 


\section{Workplace giving attitudes and motivations.}

Scholars and practitioners alike are curious about what factors "drive" individual decisionmaking behaviors (Bekkers \& Wiepking, 2011b; Konrath \& Handy, 2017; Schervish \& Havens, 1997;). Not surprisingly, individual-level interests and understandings — such as personal values and altruistic concerns - are among the most important determinants of whether and how people give (Bekkers \& Wiepking, 2011b). Workplace giving is similar in that it provides an avenue for individuals to be philanthropic (or not), but because it takes place within an organizational and social setting, it makes individual philanthropy an employer concern as well.

Roza (2016) applied the the theory of planned behavior to workplace giving. The theory asserts that individuals' intentions to do certain things are functions of their (1) perception of their ability to complete the behavior, (2) attitude toward the behavior, and (3) perceived expectations of others about the behavior (Ajzen, 1991). Two additional concerns were proposed to effect charitable giving: anxiety and past experience. Deficiencies in any of these five areas, Roza argued, may prevent employees from participating in workplace giving. If an employee is not aware of a campaign, for example, their perception of their ability to participate may be effected. Alternately, an employee may believe that their company values employee campaign participation, and thus may intend to participate for this reason. Or, an individual's intention to participate may be hindered out of anxiety about public recognition (Roza, 2016). This theory provides a lens for considering employees' philanthropic intentions, but has not been used in empirical studies of workplace giving

Examinations of motivations and attitudes about workplace giving are mostly atheoretical. Witty and Urla (1989) found that employees gave out of a moral responsibility to help, not because giving was expected by co-workers or the boss. Meanwhile, respondents said they did not give because they would rather give outside of work. Lund (1998), who studied United Way donors, at a single American university, found that $51 \%$ of donors reported giving due to a sense of institutional responsibility. A small percentage of people said they did not give because they preferred giving directly to the cause and did not like being asked to give through employer. Likewise, some Australians simply preferred to donate outside of work and to their own preferred charity/causes (Haski-Levanthal, 2012).

U.K. and Australian surveys about workplace giving often have focused on gleaning information about the functional aspects of employee attitudes on the campaigns rather than examining morals and values. In Romney-Alexander's (2002) study more than 70\% respondents said they participated because of the ease of giving through payroll deduction and the tax benefit. From analysis of U.K. national data, Potter and Scales (2008) noted that the tax benefit motivated more affluent individuals who were already workplace donors. Australian donors reported employer matching as the first reason for giving followed by the convenience and tax-effectiveness of payroll giving (Haski-Levanthal, 2012). 


\section{Position characteristics.}

A strong and consistent antecedent of philanthropic giving is salary and household income (Gittell \& Tibaldi, 2006; Rooney et al., 2001; Wiepking \& Bekkers, 2012). Compensation has likewise proven salient in workplace giving in the U.S. and U.K. Keating, Pitts, and Appel (1981) randomly surveyed 1000 people in a U.S. county about their United Way giving. Controlling for several basic demographics, the researchers found family income to be a consistent determinant for giving. In Witty and Urla's (1989) study, household income was positively associated with participation but not as much as other factors. Carman (2004) found salary to have a significant positive effect on participation and amount given. Osili and colleagues (2011) noted that those with salaries higher than $\$ 85,000$ gave more at work (but salary was more significant in giving outside of work). In the U.S. higher education setting, salary was positively correlated with donating (and usually donation amount) (Agypt et al., 2012; Borden et al., 2014; Christensen et al., 2016; Knight, 2004; Shaker et al., 2016), except in one case (Charoensap-Kelly, 2017). In the U.K. study of 8,000 payroll donors, the more people earned the more they gave through the workplace (Romney-Alexander, 2002).

Another aspect of employee-employer relationships is position type. Those who feel in control over their work typically identify strongly with their workplace (Wan-Huggins et al., 1998), suggesting that higher status, salaried employees will be likely workplace campaign participants. The research regarding position level/type is inconclusive, however, and suggests the influence of specific workplace cultures. In the U.K., one non-representative survey found that job-level within the organization related to participation (Romney-Alexander, 2002) while another using a national data set found little difference among occupational groups and participation rates (Potter \& Scales, 2008). In Australia, higher-level jobs equaled larger donations (Haski-Levanthal, 2012). In the U.S., within university-based studies, giving behaviors varied for academic and non-academic staff, though those in higher ranks of either classification were the more likely donors (Agypt et al, 2012; Borden et al., 2014; Charoensap-Kelly, 2017; Christensen et al., 2016).

As discussed, although age is generally a positive predictor of giving (Bekkers \& Weipking, 2011a), in the workplace it is an inconsistent predictor (Agypt et al., 2012; Borden et al., 2014; Osili et al., 2011). Length of service appears more relevant in its relationship to giving at work, which is logical given organizational theory that posits that employees become increasingly connected to their employers over time (Fuller, Hester, Barnett, Frey, \& Relyea, 2006). Witty and Urla (1989) found a link between years of employment and higher campaign participation, independent of income. Employment duration had a significant and positive effect on workplace giving in one large U.S. study (Carman, 2004). Borden et al. (2014) found service length to be significant in predicting giving proclivity and gift amount to the university but two other university studies did not fully support this finding (Agypt et al., 2012; Charoensap-Kelly, 2017). 


\section{Employer characteristics and behaviors.}

A significant body of scholarship examines corporate philanthropy - through which companies support causes with their resources - and corporate social responsibility, which is inclusive of corporate philanthropy as well as accountability regarding the general well-being of employees, customers, and society (Choi \& Wang, 2007; Werther \& Chandler, 2011). Researchers have explored employee understanding and responses to these espoused values and enacted behaviors (e.g. Block, Glavas, Mannor, \& Erskine, 2017; Danilovic, Hensbergen, Hoveskog, \& Zadayannaya, 2015; Onkila, 2015). Smith (2013) found that a workplace "culture of giving" led to a self-reported increase in a spectrum of philanthropic activities by employees, including greater interest in participating in workplace campaigns. Todd (2015) analyzed 22 research studies through the lens of stakeholder theory and determined that corporate culture can create barriers and facilitators for employee charitable behaviors. Indeed, Stylte (2015) found that employees' $(n=233)$ perceptions of the humility of organizational leaders at an American university significantly predicted their giving and explained some variance in (self-reported) giving behavior. In Haski-Leventhal's (2012) Australian study, high-level donors were significantly more likely to hold positive attitudes about their employer's community involvement.

Organizations feature place-specific cultures, of which corporate social responsibility is only one dimension (Ciulla, 2000; Hall, 2002). Other differentiating factors may also lead to variation in employee behavior. For example, Witty and Urla (1989) found that employees of for-profit companies gave at a higher rate than public sector employees. In Osili and colleagues' (2011) study the incidence of workplace giving and donation level varied significantly by industry and was most common in finance and education. However, industry had little influence on individual giving outside of work. Employees of larger firms were more likely to participate in workplace campaigns - a finding that was reversed in the Australian context: participation was highest at small organizations with fewer than 99 employees (Haski-Leventhal, 2012). Haski-Leventhal discovered that the above average donors were in "white collar" businesses and low-level givers were more common in "blue collar" industries. The highest rates of non-givers were in government administration and defense and wholesale trade. University-based studies also indicate differentiation among institutional types, with smaller campuses having higher participation rates but larger institutions having higher gift amounts (March, 2005; Shaker, 2013a; Shaker et al., 2016).

\section{Organizational commitment and social influence.}

Organizational identification theory argues that those employees who embrace and internalize an organization's values will be more strongly bonded to the organization and will take the organization's goals as their own (Deetz, 1992; Gossett, 2002; Tompkins \& Cheney, 1985). Employees who identify with their organizations will attend more to management messages and do more to aid the organization and their coworkers (Tomkins \& Cheney, 1985). Organizational 
commitment, meanwhile, is an outcome of the social exchange between the individual and the employer (Gouldner, 1960) and workplace giving research has shown it to be impactful.

Scholars have explored the interplay of organizational commitment with workplace giving. Raman and Zboja (2006) surveyed a small group of employees in one U.S. region whose employers had United Way campaigns $(\mathrm{n}=103)$. The employees' level of organizational commitment was significantly and positively related to the likelihood of donating, while their level of job satisfaction was not related to donating. Christensen, Nesbit, and Stritch (2017) similarly found that organization commitment was a positive indicator of workplace giving in their single-university study. Haski-Levanthal (2012) examined the relationship between employees' organizational commitment and campaign participation in a sub-sample of the Australian study. Although there were large differences in commitment among the high-level, low-level, past-, and non-donors, none were significant in the regression analysis. Borden et al. (2014) used theories of organizational commitment and identification to explore the giving of employees (back to the institution) who were also alumni. One third of the university employees in the study were alumni and the researchers concluded that these employees were more likely to give and to give more than non-alumni. Conversely, Charoensap-Kelly (2017) found that alumni status was insignificant in workplace giving. Chareonsap-Kelly also explored affective organizational commitment through open-ended questions and a likert-type Affective Commitment Scale question. Those who scored higher on the scale were more likely to give.

Research suggests that individuals are influenced in their donative behaviors when they know about others' contributions (Andreoni \& Scholz, 1998). Social influence may influence giving for positive reasons ("warm glow") or more negative ones (coercion or peer pressure) and the nature of others' influence has been found to be mixed in different contexts (Schervish \& Havens, 1997).

Using social influence theory, Carman (2004) studied a sophisticated annual campaign and noted a strong peer influence. Individual participation and contribution level were positively affected by others' giving within a work team. Those in the same salary quartile and of the same gender had the greatest influence on one another within a workgroup. Gender and race had peer effects in a study with a sample of 16,000 employees of a single U. S. university (but across more than 400 "work sites" or units) (Leslie et al., 2013). Using social role theory (gender) and social exchange theory (race) the authors found that women donated more than men, the percentage of females predicted higher participation (though not significantly), and men were more likely to participate in the campaign when there proportion of women on the team (significantly so). Regarding race, the minority employees donated less that the White employees and the percentage of minorities was positively related to giving by other minorities, but not by the White employees.

Examinations of workplace philanthropy like these are considered a fertile approach for understanding both social influence broadly and philanthropic giving more narrowly (Andreoni 
\& Scholz, 1998) as well as for studying commitment and identification with employing organizations.

\section{Solicitation strategies.}

People are more likely to be philanthropic when they are asked to give (Bekkers \& Wiepking, 2011b; Independent Sector, 2001;). Employer actions regarding campaigns can affect the donative behavior of employees. Employers (and the workplace campaigner) can influence the campaign and its solicitation strategies. A number of studies have examined how employees respond to strategies meant to encourage them to give and/or to give more.

\section{Campaign publicity.}

The research regarding how employees respond to the presence of and communication about a workplace campaigns is disparate but suggests that communication is a key, albeit not-alwaysappreciated necessity of workplace campaigning. A university-based study about United Way contributions found a significant positive relationship between awareness of the campaign and individual participation (Lund, 1998). High-level donors were more prone to agree that they received the right amount of information about the workplace campaign in Haski-Leventhal's (2012) Australian study. In the U.K., most people learned about the option to donate through payroll through a promotion in their workplace (Romney-Alexander, 2002). Ninety percent of participants had not been asked to increase how much they gave. Fifty percent of high-level donors had increased their participation anyway while $25 \%$ of lower givers had never thought of changing their donation before. In another U.K. study, using a survey of 750 companies, the researchers found that rates of participation were no higher for companies with more established (older) payroll giving campaigns (The Giving Campaign, 2009). Characteristics of high participation companies were strategic communication, leadership endorsement of campaign, recognized business benefits, and a provision for matching. Nesbit et al.'s (2012) participants noted frequent email and print communications as motivating participation, though some did not appreciate the techniques used to "push" for participation. On days with email reminders $1.3 \%$ more people donated and $\$ 2,371$ more was given.

\section{Solicitor.}

The individual or entity that asks for the gift or promotes a cause can influence individuals' giving decisions (Bekkers \& Wiepking, 2011b). Employees sometimes respond negatively to these efforts and research shows mixed outcomes. Two hundred faculty donors from three universities reported a distaste for (perceived) pressure from their peers (Holland, 1997; Holland $\&$ Miller, 1999). Moreover, these participants said that neither phone calls nor visits from professional fundraisers were relevant to their gift decisions. Conversely, academic fundraisers from 164 institutions reported that academic faculty and staff participated at greater rates if personally asked by peers, a volunteer campaign chair, or the university president (March, 2005). Lund's (1998) survey of United Way participants indicated that the donors positively percieved 
volunteer leaders. Those who experienced social pressure - encouragement from their employer and supervisor to give - were more likely to give and to give more than those who did not, according to Keating, Pitts, and Appel (1981). Schervish and Havens (1997) researched philanthropic behavior and asked a few questions with relevance for the workplace context. They found that people self-reported a positive effect on giving more money when asked by friends/business associates. The analysis showed a significant negative effect when the employer encouraged their giving. Conversely, in a national data set, coworker campaign endorsement had a significant and negative effect on gift amounts but no effect on giving likelihood (Shaker et al., 2017). When employers encouraged participation, however, it had a strong positive significance on participation and a negative (nonsignificant) effect on donation amount.

\section{Employer matching.}

Employers, individual and foundation donors, governments and nonprofits all may provide matches for donor dollars (CECP, 2017; Walker, 2016). Individuals tend to report that they appreciate and are motivated by matches but research from various countries (U.S., Germany, U.K.) shows mixed results regarding whether matches actually influence giving (Huck \& Rasul, 2008; Karlan \& List, 2005; Sanders, Reinstein \& Tupper, 2014; Walker, 2016).

Company matching programs enable employees to deploy organizational funds for their own charitable priorities. A survey of 258 transnational companies found that nine out of ten companies offered matching, an average of $9 \%$ of employees used the matches, and that companies matched an average of $\$ 1.98$ million in employee gifts (CECP, 2017). In the U.K. around two-fifths (39\%) of the "top companies who provide funding for UK charities offer their employees a matched funding scheme (155 companies out of 400)" (Walker, 2016, p. 18).

Research reports show that employees appreciate company matching programs (Achieve, 2015; Australian Charities Fund, 2014; CAF, 2011; Cone Communications, 2016; Walker, 2016). A few empirical studies found that company matches made a difference in employee behavior. Business school alumni were $8 \%$ more likely to say they would donate to their alma maters through the workplace when company matches were available (Okunade \& Berle, 1997). Shaker, Christensen, and Bergdoll (2017) found that the presence of a matching program significantly impacted employees' inclination to give and their gift amount. And, in the Australian context, employee participation rates were significantly related to matching program availability (HaskiLeventhal, 2012).

\section{Macro/outside dynamics}

Barman (2006, 2007) explored how macro-level factors affect workplace philanthropy, noting that nonprofit organizations are constrained by society (just as individual donors are) and, thus, relationships with the social context effect individual giving behavior. Consideration of organizational field, Barman (2007) argued, allows researchers to study the social embeddedness of charitable giving and nonprofit and donor behavior. Researchers have examined the effect of 
organizational competitors on workplace fundraising organizations (Paarlberg \& Hwang, 2017) and how local context might mediate field level pressures on workplace campaigners (Paarlberg \& Meinhold, 2012), but these usually do not include individual level analysis.

As with micro- and meso-level giving, there is an intersection between meso- and macro-level concerns, because conditions and trends within the organizational field - such as the realization that donors should be able to designate their gifts or the ongoing debate about what level of overhead cost expenditures are appropriate-influence how organizations fundraise. The field also influences individuals' perceptions of organizations in particular or charities in general.

\section{Donor choice.}

In the U.K., payroll donors give through agencies that redistribute the funds to the designated charities (Romney-Alexander, 2002). Freedom to choose the charity was important to $98 \%$ of the U.K. donors and has proven important in the U.S. as well. In the U.S. employees typically can select among charities, but the range of choice is at employers' discretion and is a output of the organizational field (America's Charities, 2013; Barman, 2008; National Committee for Responsive Philanthropy, 2003). Witty and Urla (1989) reported that forty one percent of their San Francisco Bay area respondents preferred the ability to give to a specific program, 21\% preferred giving through a federation, and 38\% preferred the option to do both. A study of the Washington State combined fund drive showed that individual donors gave the most to individual charities (39\%) followed by the United Way (26\%), other giving federations (21\%) and to unspecified organizations (13\%) (Krishnamurthy, 2000). Employees who had a choice of charities were likely to give more, holding other variables constant in a nationally-representative U.S. study (Shaker et al., 2017). March's (1997) research on university campaigns for internal purposes found that faculty and staff usually made restricted gifts and Shaker's (2013b) study of faculty donors showed that all designated their large gifts for specific and limited purposes. These studies illustrate donor choice as a meso-level aspect of workplace giving and show the overlap among dynamics.

Barman's (2007) work demonstrates macro-level influence on donor choice. Barman completed a historical comparative analysis of donor control within United Way campaigns in the American cities of San Francisco and Chicago. Chicago donors designated gifts at a low rate (19\% in the most recent data before the study) and San Francisco donors designated their gifts at a high rate (83\%). Barman argued that micro-level explanations of the phenomenon fell short and that the designation differences were driven by the structure and dynamics of workplace charity broadly in the two cities. As a result, one of the United Ways encouraged earmarking of donations and the other discouraged them. This in turn effected the solicitation strategies and ultimately the donor behavior. 


\section{Discussion}

The conceptual model described in this paper illustrates what we know about workplace giving organized around a number of variables at the micro-, meso-, and macro-levels. Certainly there is evidence that dynamics at each of these levels matter to workplace giving. While many studies include individual-level factors widely known to shape philanthropic decisions in general, a few of these are starting to distinguish individual-level factors that may operate uniquely in the context of workplace philanthropy. We see strength in the workplace giving literature in the area of meso-level dynamics - a natural level at which to focus on the influence of the employer and nonprofit workplace campaign members. But our review also underscores a few things that we do not know.

Certainly there is interplay between these 'nested' levels, but one of our initial assessments of the literature is that, to date, those interplays, e.g., moderated relationships, have been underresearched. There are a few exceptions. For example, Christensen, Nesbit, and Stritch (2017) looked at the interplay between micro-level PSM and meso-level organizational commitment. They found the interaction term to be significant. Future research might also take up the ethical concerns based on the interplay of the power relationship of employer or supervisor with an individual employee; peer pressure in a work campaign similarly raises the interplay of micro- and meso-level factors.

Our second observation is that the macro level is understudied. Barman's (2006) seminal work regarding changing and contested communities of philanthropy provided one of the earlier perspectives on workplace philanthropy at this level, but it remains one of the only macro-level studies. We see this as an important opportunity in need further research.

Much of the workplace giving research remains siloed in respective geographic settings and there is very little analysis from countries other than the U.S. Through the macro lens, future researchers might consider transnational differences in workplace giving. Because the nonprofit landscape and fundraising context is diverse (Breeze \& Scaife, 2015) one can extrapolate that the mechanisms, approaches, and capacities for workplace philanthropy vary, leading to behavioral differences among people of different nations. Indeed, from the discussion of the U.S., U.K., and Australia in this paper, one can see that while there are behavioral similarities among employees, there are also differences, in part a likely result of differing labor histories, governmental tax programs, NGO sector "maturity", social attitudies toward philanthropy, and the like. Comparative research could bring further instights because research in this domain is poorly developed.

\section{Conclusion}

Empirical knowledge about workplace giving is growing but, as this study shows, it is not even enough across the relevant levels of inquiry (micro-, meso-, macro-). Researchers interested in how giving at work may differ from, compare to, or effect giving more broadly (Agypt et al., 
2012; Osili et al., 2011). Workplace donors are not homogenous and the workplace is a microcosm of a society with individuals at every level of philanthropic inclination. While it may mirror society, the workplace requires special analysis and theory because of its unique factorse.g., coworkers, company policies - that affect giving. Thus far, research is inconclusive about who among workplace donors is most likely to give, to give more, or to give for what purpose.

The field would benefit from a deeper understanding about how (and if) personal choices and traits (such as religious orientation) are relevant at work as well as to better examine phenomenon such as crowding out and donor confidence in the nonprofit sector. A notable proportion of workplace giving research was conducted within higher education settings, bringing disproportionate attention to one segment of the workplace. Few empirical studies have been conducted outside of the U.S. Many of the extant studies are under-theorized, making it difficult for scholars and practitioners alike to consider the findings across multiple contexts. Few studies bring donor voice to the forefront through qualitative methods, leading to a lack of nuanced information about decision-making and behavior. Few studies include the perspectives of workplace fundraisers/marketers/volunteers. Only infrequently is actual giving data combined with self-reported perceptions of workplace solicitation.

Each deficit in the literature provides opportunities for researchers to contribute new knowledge through a variety of methodologies. An enriched knowledge base would help marketers (and indeed the whole nonprofit sector) know how and where to best dedicate energies and resources to grow giving within individual workplaces. Supplemental research would serve scholarly and practical purposes, deepening functional knowledge, enhancing theoretical understandings of the current context of workplace giving, and determining the importance of workplace giving with the broader landscape of charitable contributions. 


\section{Bibliography}

Achieve. (2015). The 2015 millennial impact report: Cause, influence \& the next generation [Report]. Available from http://www.themillennialimpact.com/

Agypt B., Christensen R. K., \& Nesbit, R. (2012). A tale of two charitable campaigns: Longitudinal analysis of employee giving at a public university. Nonprofit and Voluntary Sector Quarterly, 41(5): 802-825.

Ajzen, I. (1991). The theory of planned behavior. Organizational Behavior and Human Decision Processes, 50(2), 179-211.

America's Charities (2013) Snapshot: Trends and Strategies to Engage Employees in Greater Giving. Available from https://www.charities.org/sites/default/files/Snapshot2013_Engage_Employees_Workpla ce Giving by America $\% 27 \mathrm{~s} \% 20$ Charities.pdf

Andreoni, J., Brown, E., \& Rischall, I. (2003). Charitable giving by married couples: Who decides, and why does it matter? Journal of Human Resources, 38(1), 111-133.

Andreoni, J., \& Scholz, J. K. (1998). An econometric analysis of charitable giving with interdependent preferences. Economic Inquiry, 36(3), 410-428.

Australian Charities Fund. (2016). Young Australians motivations for workplace giving [Report] Centre For Social Impact. Available from http://australiancharitiesfund.org.au/wpcontent/uploads/2016/04/ACF-Young-Australians-Research-Report-LR.pdf

The Australian Charities Fund, (2014). Workplace giving: Business and employee insights [AskU.com.au Infographic: Working Australians want to give through the workplace]. Retrieved from http://australiancharitiesfund.org.au/workplace-giving-businessemployee-insights-2014/ .

Australian Taxation Office. (2018). Taxation statistics 2014-15 [Individuals summary tables and charts] Available from https://www.ato.gov.au/About-ATO/Research-and-statistics/Indetail/Taxation-statistics/Taxation-statistics-2014-15/?anchor=Individuals\#Table7 .

Barber, P., \& Levis, B. (2013). Donor retention matters. Urban Institute: Center on Nonprofits and Philanthropy. Available from https://www.urban.org.

Barman E. (2006). Contesting communities: The transformation of workplace charity. Stanford University Press: Stanford, CA.

Barman, E. (2007). An institutional approach to donor control: From dyadic ties to a field-level analysis. American Journal of Sociology, 112(5), 1416-1457.

Barman, E. (2008). With strings attached: Nonprofits and the adoption of donor choice. Nonprofit and Voluntary Sector Quarterly, 37(1), 39-56.

Bekkers, R., \& Wiepking, P. (2011a). Who gives? A literature review of predictors of charitable giving part one: religion, education, age and socialisation. Voluntary Sector Review, 2(3), 337-365.

Bekkers, R., \& Wiepking, P. (2011b). A literature review of empirical studies of philanthropy: Eight mechanisms that drive charitable giving. Nonprofit and Voluntary Sector Quarterly, 40(5), 924-973.

Block, E. S., Glavas, A., Mannor, M. J., \& Erskine, L. (2017). Business for good? An investigation into the strategies firms use to maximize the impact of financial corporate philanthropy on employee attitudes. Journal of Business Ethics, 146(1), 167-183. 
Borden, V. M. H., Shaker, G. G., \& Kienker, B. L. (2014). The impact of alumni status on institutional giving by faculty and staff. Research in Higher Education. DOI: 0.1007/s11162-013-9318-3.

Breeze. B., \& Scaife, W. (2015). Encouraging generosity: The practice and organization of fundraising across nations. In P. Wiepking \& F. Handy (Eds). The Palgrave handbook of global philanthropy (pp. 597-623). Houndsmills, Basingstoke, Hampshire; New York, NY: Palgrave Macmillian.

Brown, E. (2005). College, social capital, and charitable giving. In A. Brooks (Ed.), Gifts of time and money in America's communities (pp. 185-204). Lanham, MD: Rowman \& Littlefield.

Brown, E., \& Ferris, J. M. (2007). Social capital and philanthropy: An analysis of the impact of social capital on individual giving and volunteering. Nonprofit and Voluntary Sector Quarterly, 36(1), 85-99.

Carman, K. G. (2004). Social influences and the private provision of public goods: Evidence from charitable contributions in the workplace. (Unpublished manuscript). Palo Alto, CA: Stanford University.

Choi, J., \& Wang, H. (2007). The promise of a managerial values approach to corporate philanthropy. Journal of Business Ethics, 75(4), 345-359.

CECP, in association with The Conference Board. (2015) Giving in Numbers: 2015 Edition.

CECP, in association with The Conference Board. (2017) Giving in Numbers: 2017 Edition.

Charoensap-Kelly, P. (2017). Crafting a faculty and staff fundraising campaign: Predictors of giving, donor motivations and effective strategies. Journal of Education Advancement \& Marketing, 2(1), 20-37.

Charities Aid Foundation (2011). CAF UK Giving 2011: An overview of Charitable Giving in the U.K. Kent, UK.

Charities Aid Foundation (2015). CAF UK Giving 2015: An overview of Charitable Giving in the U.K. Kent, UK.

Charities Aid Foundation (2017). CAF UK Giving 2017: An overview of Charitable Giving in the U.K. Kent, UK.

Christensen, R. K., Nesbit, R., \& Agypt, B. (2016). To give or not to give: Employee responses to workplace giving campaigns over time. Nonprofit and Voluntary Sector Quarterly, 45(6), 1258-1275.

Christensen, R. K., Nesbit, R., \& Stritch, J. M. (2017). The role of employees' public service motives and organizational commitment in workplace giving campaigns. The American Review of Public Administration, 0275074017701223.

Christensen, R. K., Stritch, J. M., Kellough, J. E., \& Brewer, G. (2015). Public service orientation among new college freshmen: Identifying motives and traits relevant to service-learning and engagement. Journal of Higher Education Outreach and Engagement, 19(4), 39-62.

Ciulla, J. B. (2000). The working life: The promise and betrayal of modern work. New York: Three Rivers Press.

Cone Communications. (2016.) The 2016 Cone Communications employee engagement study. Available from http://www.conecomm.com/research-blog/2016-employee-engagementstudy 
Danilovic, M., Hensbergen, M., Hoveskog, M., \& Zadayannaya, L. (2015). Exploring diffusion and dynamics of corporate social responsibility. Corporate Social Responsibility and Environmental Management, 22(3), 129-141.

Deetz, S. (1992). Democracy in an age of corporate colonization: Developments in communication and the politics of everyday life. Albany, NY: SUNY Press.

Fuller, J. B., Hester, K., Barnett, T., Frey, L., \& Relyea, C. (2006). Perceived organizational support and perceived external prestige: Predicting organizational attachment for university staff, faculty, and administrators. The Journal of Social Psychology, 146, 327347.

Gittell, R., \& Tebaldi, E. (2006). Charitable giving: Factors influencing giving in U.S. states. Nonprofit and Voluntary Sector Quarterly, 35, 721.

Giving USA. (2007). Giving USA. Giving USA Foundation: Chicago, IL.

Gossett, L. (2002). Kept at arm's length: Questioning the organizational desirability of member identification. Communication Monographs, 69(4), 385-404.

Gouldner, H. P. (1960). Dimensions of organizational commitment. Administrative Science Quarterly, 468-490.

Hall, D. T. (2002). Careers in and out of organizations. Thousand Oaks, CA: Sage.

Haski-Levanthal, D. (2013). Employee engagement in CSR: The case of payroll giving in Australia. Corporate and Social Responsibility and Environmental Management, 20, 113128. DOI: $10.1002 / \mathrm{csr} .1287$

Healy, K. (2004). Altruism as an organizational problem: The case of organ procurement. American Sociological Review, 69, 387-404.

Holland, A. P. (1997). Faculty motivations for giving to their employing institutions. Dissertation Abstracts International (UMI. 9735711)

Holland A. P., \& Miller, M. T. (1999). Faculty as donors: Why they give to their employing institutions. (ERIC Document Reproduction Service No. ED439648)

Houston, D. J. (2006). Walking the walk of public service motivation: Public employees and charitable gifts of time, blood, and money. Journal of Public Administration Research and Theory, 16, 67-86.

Huck, S., \& Rasul, I. (2008). Testing consumer theory in the field: private consumption versus charitable goods [Report]. University College London.

Independent Sector. (2001). Giving and volunteering in the United States. Independent Sector: Washington, DC.

Karlan, D. \& List, J. A. (2005). Does price matter in charitable giving? Evidence from a largescale natural field experiment. National Bureau of Economic Research Working Paper 12338.

Keating, B., Pitts, R., \& Appel, D. (1981). United way contributions: Coercion, charity or economic self-interest? Southern Economic Journal, 47, 816-823.

Knight, W.E. (2004). Influences on participation in a university faculty and staff annual giving campaign. The CASE International Journal of Educational Advancement, 4(3), 221-232.

Konrath, S., \& Handy, F. (2017). The development and validation of the motives to donate scale. Nonprofit and Voluntary Sector Quarterly. DOI: https://doi.org/10.1177/0899764017744894

Kooij, D. T., Jansen, P. G., Dikkers, J. S., \& De Lange, A. H. (2010). The influence of age on the associations between HR practices and both affective commitment and job satisfaction: A meta-analysis. Journal of Organizational Behavior, 31(8), 1111-1136. 
Krishnamurthy, S. (2002). The Washington State combined fund drive: A case study. International Journal of Nonprofit and Voluntary Sector Marketing, 7(1), 45-54.

Leslie, L. M., Snyder, M., \& Glomb, T. M. (2013). Who gives? Multilevel effects of gender and ethnicity on workplace charitable giving. Journal of Applied Psychology 98(1), 49-62.

Lichtenstein, D. R., Drumwright, M. E., \& Braig, B. M. (2004). The effect of corporate social responsibility on customer donations to corporate-supported nonprofits. Journal of Marketing, 68(4), 16-32.

Lund, C. (1998). Analysis of Rochester Institute of Technology's United Way campaign [Thesis]. Available from http://scholarworks.rit.edu/theses/7387/

March, K. S. (2005). A descriptive study of faculty and staff giving practices at public institutions of higher education within the United States [Doctoral dissertation]. State University of New York at Buffalo. Available from https://ubir.buffalo.edu/xmlui/handle/10477/45153

Mesch, D. J., Rooney, P. M., Steinberg, K. S., \& Denton, B. (2006). The effects of race, gender, and marital status on giving and volunteering in Indiana. Nonprofit and Voluntary Sector Quarterly, 35(4), 565-587.

Meslin, E. M., Ronney P. M., \& Wolf, J. G. (2008). Health-related philanthropy: Toward understanding the relationship between the donation of the body (and its parts) and traditional forms of philanthropic giving. Nonprofit and Voluntary Sector Quarterly, 37, 44-62.

Musick, M. A., \& Wilson, J. (2008). Volunteers: A social profile. Bloomington: Indiana University Press.

National Committee for Responsive Philanthropy. (2003). Giving at Work 2003. Washington, DC.

Nesbit, R., Christensen, R. K., \& Gossett, L. (2012). Charitable Giving in the Public Workplace: A Framework to Understand Employees' Philanthropic Performance. Public Performance \& Management Review, 35(3), 449-474.

Nesbit, R., Myser, S., Paarlberg, L. E., Christensen, R. K., Clerkin, R. M., \& Tschirhart, M. (2013, January). Packing and unpacking philanthropy: How geographic moves affect giving and volunteering. In Academy of Management Proceedings (Vol. 2013, No. 1, p. 16662). Academy of Management.

Okunade, A. A., \& Berl, R. L. (1997). Determinants of charitable giving of business school alumni. Research in Higher Education, 38(2), 201-214.

Osili, U. O., Hirt, D. E., \& Raghavan, S. (2011). Charitable giving inside and outside the workplace: the role of individual and firm characteristics. International Journal of Nonprofit and Voluntary Sector Marketing 16(4), 393-408.

Ostrander, S. A., \& Schervish, P. G. (1990). Giving and getting: Philanthropy as a social relation. Critical Issues in American Philanthropy, 67-98.

Onkila, T. (2015). Pride or embarrassment? Employees' emotions and corporate social responsibility. Corporate Social Responsibility and Environmental Management, 22(4), 222-236.

O'Reilly III, C. A., Caldwell, D. F., \& Barnett, W. P. (1989). Work group demography, social integration, and turnover. Administrative Science Quarterly, 21-37.

Paarlberg, L. E., \& Hwang, H. (2017). The heterogeneity of competitive forces: The impact of competition for resources on United Way fundraising. Nonprofit and Voluntary Sector Quarterly, 46(5), 897-921. 
Paarlberg, L. E., \& Meinhold, S. S. (2012). Using institutional theory to explore local variations in United Way's community impact model. Nonprofit and Voluntary Sector Quarterly, 41(5), 826-849.

Perry, J. L., \& Wise, L. R. (1990). The motivational bases of public service. Public Administration Review, 367-373.

Potter, V., \& Scales, J. (2008). Review of payroll giving. London: Strategy Complete.

Raman, P., \& Zboja, J. J. (2006). The effects of employee attitudes on workplace charitable donations. Journal of Nonprofit \& Public Sector Marketing, 16(1-2), 41-60.

Romney-Alexander D. (2002). Payroll giving in the UK: Donor incentives and influences on giving behaviour. International Journal of Nonprofit and Voluntary Sector Marketing 7(1), 84-92.

Rooney, P. M., Steinberg, K. S., \& Schervish, P. G. (2001). A methodological comparison of giving surveys: Indiana as a test case. Nonprofit and Voluntary Sector Quarterly, 30(3), 551-568.

Roza, L. (2016). Employee engagement in corporate social responsibility [Dissertation]. (No. EPS-2016-396-ORG). Available from https://repub.eur.nl/pub/93254/EPS20163960RG.pdf

Sanders, M., Reinstein, D., \& Tupper, A. (2014, May). Worth 1000 Words: The effect of social cues on a fundraising campaign in a government agency. A field experiment. Working Paper No. 14/324. Bristol, U.K.: Centre for Market and Public Organisation, University of Bristol.

Schervish, P. G., \& Havens, J. J. (1997). Social participation and charitable giving: A multivariate analysis. Voluntas: International Journal of Voluntary and Nonprofit Organizations, 8(3), 235-260.

Shaker, G. G. (2013a). Giving on campus: Faculty and staff as prospects and donors In N. Drezner (Ed.), Expanding the donor base in higher education: Engaging non-traditional donors. New York: Routledge.

Shaker, G. G. (2013b). The generosity of the professoriate: Faculty as donors and academic citizens. Metropolitan Universities, 23(3), 5-25.

Shaker, G. G., Borden, V. M. H., \& Kienker, B. L. (2016). Workplace giving in universities: A U.S. case study at Indiana University. Nonprofit and Voluntary Sector Quarterly, 45(1), 87-111. DOI: 10.1177/0899764014565468

Shaker, G. G. \& Christensen, R. (2017, October 27). What works in workplace giving. The Conversation, United States Edition. Available from https://theconversation.com/whatworks-in-workplace-giving-81243.

Shaker, G. G., Christensen, R., \& Berdoll, J. (2017). What works at work? Towards an integrative model examining workplace campaign strategies. Nonprofit Management \& Leadership 28(1), 25-46. DOI: 10.1002/nml.21270

Smith, J. M. (2013). Philanthropic identity at work: Employer influences on the charitable giving attitudes and behaviors of employees. The Journal of Business Communication, 50(2), 128-151.

Smyllie, S. \& Arias, D. (2016).Workplace giving. In W. Scaife, M. McGregor-Lowndes, J. Barraket, \& W. Burns, (Eds) Giving Australia 2016 (136-149). Brisbane, Queensland: The Australian Centre for Philanthropy and Nonprofit Studies, Queensland University of Technology, Centre for Social Impact, Swinburne University of Technology and the Centre for Corporate Public Affairs. 
Straub, J. D. (2003). Fundraising and crowd-out of charitable contributions: New evidence from contributions to public radio [Working Paper]. Texas A\&M University (Department of Economics).

Sylte, K. A. (2015). A predictive study of leader-demonstrated humility characteristics and employee giving and volunteering [Dissertation]. Northcentral University. Available from https://search.proquest.com/docview/1744837795?pq-origsite=gscholar

The Giving Campaign. (2009). The business of giving: A summary report of the business benefits of payroll giving. The Giving Campaign: London

Todd, R. W. (2015). Corporate culture's influence on employee charitable giving and volunteering (Doctoral dissertation). University of Maryland.

Tompkins, P. K., \& Cheney, G. (1985). Communication and unobtrusive control in contemporary organizations. Organizational Communication:Traditional Themes and New Directions, 13, 179-210.

Walker, C. (2016). A great match: How match-funding incentivizes chartiable giving the UK and unites funders and donors in tackling social issues. Commissioned by the Big Give, Charities Trust, and RBS. Available from http://www.charitiestrust.org.uk/downloads-1/

Wan-Huggins, V. N., Riordan, C. M., \& Griffeth, R. W. (1998). The development and longitudinal test of a model of organizational identification. Journal of Applied Social Psychology, 28(8), 724-749.

Werther, W. B., \& Chandler, D. (2011). Strategic corporate social responsibility. Sage: Thousand Oaks, CA.

Wiepking, P., \& Bekkers, R. (2012). Who gives? A literature review of predictors of charitable giving. Part Two: Gender, family composition and income. Voluntary Sector Review, 3(2), 217-245.

Wiepking, P., \& Handy, F. (2015). The Palgrave handbook of global philanthropy. Houndmills, Basingstoke, Hampshire: Palgrave Macmillan.

Wilson, C. (2015). The 2015 Koda Capital non-profit sector review. Brisbane: Koda Capital. [Presentation] Available from http://www.slideshare.net/DavidKnowles8/the-2015-kodacapital-nonprofit-sector-review.

Witty, C.J. \& Urla, J. (1989). Workplace giving: Employee attitudes, perceptions, and behavior. Working Paper No. 9. San Francisco, CA: University of San Francisco, Institute for Nonprofit Organization Management. Available from https://repository.usfca.edu/cgi/viewcontent.cgi?referer=https://scholar.google.com/\&http sredir $=1 \&$ article $=1016 \&$ context $=$ inom

Wu, S.-Y. (2004). Tax effects on charitable giving in the presence of uncertainty. Public Finance Review, 32(5), 459-482. 